\title{
PROTECTION OF LEAD STORED IN MUSEUM STORAGE CABINETS AGAINST CORROSION BY MEANS OF VAPOUR PHASE CORROSION INHIBITORS
}

\author{
${ }^{1}$ Kristýna Charlotte STRACHOTOVÁ, ${ }^{2}$ Milan KOUŘIL \\ ${ }^{1}$ University of Chemistry and Technology, Prague, Department of Metals and Corrosion Engineering, \\ Prague, Czech Republic, EU, strachok@vscht.cz \\ 2University of Chemistry and Technology, Prague, Department of Metals and Corrosion Engineering, Prague, \\ Czech Republic, EU, kourilm@vscht.cz
}

https://doi.org/10.37904/metal.2020.3576

\begin{abstract}
High sensitivity of lead to organic compounds leads to degradation of lead artifacts stored in the museums or archives together with organic materials (wood, glue, leather, paper, plastic, etc.). Protection of the lead stored under adverse conditions (environment polluted by organic compound, mainly acetic acid) is based on the use of corrosion inhibitors. The aim of this work was to test compounds with high tendency to sublime under atmospheric conditions and good ability to form a protective polymeric layer on the lead surface. The effect of volatile corrosion inhibitors mentioned in the literature (benzotriazole, cyclohexylamine carbonate, dicyclohexylamine nitrite, urotropine and sodium benzoate) was tested directly by weight loss measurement and by the resistometric method in humid atmosphere with various acetic acid vapour concentrations. The damage of lead was characterized by X-ray diffraction analysis and scanning electron microscopy. The greatest inhibition efficiency in all corrosive atmospheres and for non-treated and corroded lead samples was achieved by cyclohexylamine carbonate.
\end{abstract}

Keywords: Volatile corrosion inhibitors, lead corrosion, conservation

\section{INTRODUCTION}

One of the several possibilities how to prevent corrosion is application of volatile corrosion inhibitors (VCls). This kind of temporary protection is prospectively efficient for metals under inappropriate conditions of storage or transport [1-5], for example museum and archive storage cabinets with atmosphere polluted with volatile organic compounds (VOCs) [6]. VOCs are produced during the degradation process of organic materials (wood, glues, colours, etc.) stored in the cabinets [1, 6-9]. The concentration of emitted organic acids (especially acetic acid) inside museum storage cabinets are at levels less than $500 \mathrm{ppb}$ [10]. Acetic acid vapours accelerate atmospheric corrosion of lead, the material of important cultural heritage artifacts usually stored in museum storage cabinets even at low concentration $(0.1-1 \mathrm{ppm})$ [11]. Due to the corrosion process of lead the surface details of artifacts may get los tor the artifacts can eventually disintegrate completely [6]. $\mathrm{VCl}$ compounds are able to vaporize (e.g. vapour pressure of benzotriazole and sodium benzoate is $0.09 \mathrm{~Pa}$ and $4.9 \times 10^{7} \mathrm{~Pa}$, respectively [5]) into the cabinet environment and then adsorb on the metal surface. $\mathrm{VCl}$ compounds form a thin protective monomolecular barrier film over the metal surface [1-5]. Sodium benzoate, cyclohexylamine carbonate and dicyclohexylamine nitrite are usually used as corrosion inhibitors for lead in atmospheric conditions. Whereas benzotriazole (BTA) or amines are usually used as corrosion inhibitors for lead in organic acids conditions [12]. In this paper, corrosion inhibitors which have been carried out on inhibitor coatings in previous research work [13] are examined. 


\section{EXPERIMENTAL PART}

\subsection{Materials}

BTA (1, 2, 3-benzotriazole, $\left.\mathrm{C}_{6} \mathrm{H}_{5} \mathrm{~N}_{3}\right)$, cyclohexylamine carbonate $\left(\left(\mathrm{C}_{6} \mathrm{H}_{11} \mathrm{NH}_{2}\right)_{2} \mathrm{CO}_{2}\right)$, dicyclohexylamine nitrite $\left(\left(\mathrm{C}_{6} \mathrm{H}_{11}\right)_{2} \mathrm{NH}_{2} \mathrm{NO}_{2}\right)$, urotropine (Hexamethylenetetramine, $\left.\mathrm{C}_{6} \mathrm{H}_{12} \mathrm{~N}_{4}\right)$ and sodium benzoate $\left(\mathrm{C}_{6} \mathrm{H}_{5} \mathrm{COONa}\right)$ were used as volatile corrosion inhibitors ( $\mathrm{VCls}$ ). Corrosive atmosphere was provided by aqueous solutions of acetic acid in various concentrations $\left(0.001,0.01\right.$ and $\left.0.1 \mathrm{~mol}^{-1} \mathrm{l}^{-1}\right)$.

In this work, lead samples $(99.9 \% \mathrm{~Pb}, 20 \times 20 \times 1 \mathrm{~mm})$ were used with two different surface states: non-treated surface was obtained by water grinding of the samples surface with SiC grinding paper up to grit P800, subsequent rinsing by distilled water and ethanol; corroded surface (simulating of the original patina on lead) was obtained by exposure of the non-treated lead samples into humid acetic acid atmosphere (above 0.01 mol. $\left.\right|^{-1}$ acetic acid aqueous solution) for 72 hours, subsequent rinsing by distilled water and ethanol. Lead resistometric sensors (97\% Pb, $1.5 \% \mathrm{Sn}, 1.5 \% \mathrm{Sb}$, initial thickness of lead foil was $25 \mu \mathrm{m}$ ) surface state was prepared in similar way like the samples with non-treated surface states: sensor surface was dry grinded with abrasive wadding (3M Scotch-Brite CF-MF), subsequent rinsing with distilled water and ethanol.

\subsection{Methods}

The weight gain measurement and the resistometric measurement based on ISO 11844-2:2006 were used. The resistometric sensors were placed individually into the closed boxes with the volume of 10 litres and connected with ACD-03 (AC Corrosion Detector; MetriCorr). In each of the boxes, there was a ventilator, a Petri dish with one of the $\mathrm{VCls}$ and a beaker with $100 \mathrm{ml}$ of acetic acid solution. The resistometric measurement took place at room temperature and had following procedures: 1. stabilisation of the sensors (2 hours), 2. grinding of the sensors with abrasive wadding, 3. exposition of the sensors in the box with $\mathrm{VCl}$ and acetic acid solution in concentration 0.001 mol. $\mathrm{I}^{-1}$ (100 hours), 4. exposition of the sensors in the box with $\mathrm{VCl}$ and acetic acid solution in concentration 0.01 mol..$^{-1}$ (140 hours), 5 . exposition of the sensors in the box with $\mathrm{VCl}$ and acetic acid solution in concentration $0.1 \mathrm{~mol} \cdot \mathrm{l}^{-1}$ (56 hours). The corrosion rate ( $\left.r_{\text {corr }}\right)$ in last 24 hours of exposure part was calculated as guideline of dependence corrosion decrease with time linear regression line. The weight gain measurement was performed in the closed boxes with volume of 10 litres without ventilator at room temperature for twenty-eight days. In each of the boxes there was a Petri dish with one of the VCls, six lead samples (three of the samples with non-treated surface and three of the samples with corroded surface) and a beaker with $100 \mathrm{ml}$ of acetic acid solution in different concentration $\left(0.001,0.01\right.$ and $\left.0.1 \mathrm{~mol}^{-1}\right)$. All the samples were weighted before and after exposure into the box with $\mathrm{VCl}$ and acetic acid environment to obtain the weight gain. The corrosion weight gain $\left(r_{\mathrm{mi}}\right)$ is an average of three values.

The chemical composition of the surface was analyzed by diffractometer X'Pert PRO (PANanalytical B.V.). Samples surface was observed by optical microscope Olympus PME 3 and surface morphology was observed by SEM Tescan VEGA 3.

\section{RESULTS AND DISCUSSION}

\subsection{Resistometric method}

Figure 1 and Table 1 report on the long-time resistometric measurement of lead with non-treated surface and with or without $\mathrm{VCl}$ in atmosphere above acetic acid solution at different concentrations $(0.001,0.01$ and $\left.0.1 \mathrm{~mol} \cdot \mathrm{I}^{-1}\right)$. The sensor without $\mathrm{VCl}$ began to corrode rapidly in atmosphere above $0.01 \mathrm{~mol} \cdot \mathrm{l}^{-1}$ acetic acid solution. In this atmosphere the sensors with presence of different VCls (except of dicyclohexylamine nitrite) were very resistant. In the atmosphere above $0.1 \mathrm{~mol}^{-1}$ acetic acid solution, only sensors with cyclohexylamine carbonate and sodium benzoate presence were resistant. The cumulative consumption of VCls during the 
resistometric measurement (mainly in the part of sensors exposition in atmosphere above $0.1 \mathrm{~mol}^{-1} \mathrm{f}^{-1}$ acetic acid solution) was $14 \mathrm{~g}$ of urotropine, $9 \mathrm{~g}$ of cyclohexylamine carbonate, $7 \mathrm{~g}$ of sodium benzoate and $0 \mathrm{~g}$ of BTA and dicyclohexylamine nitrite.

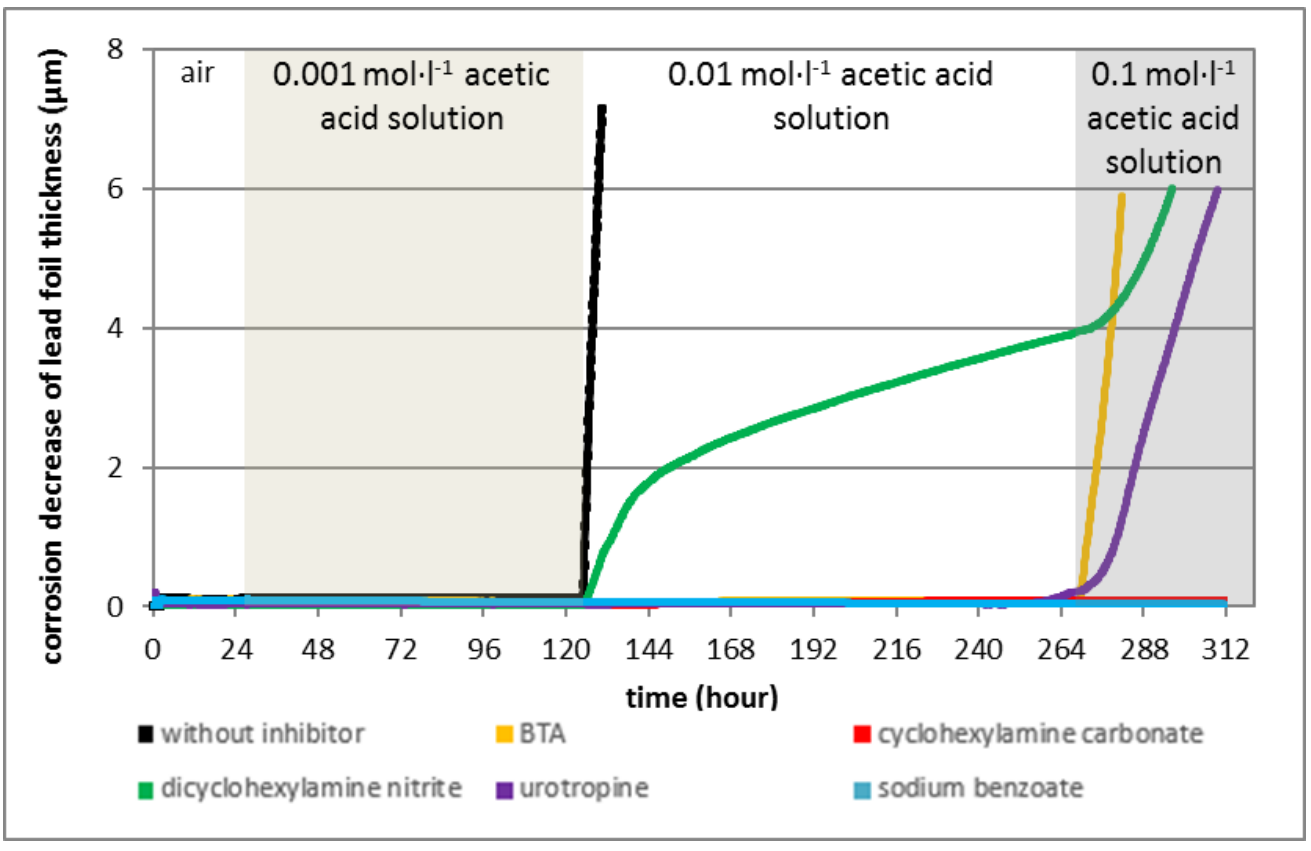

Figure 1 Resistometric measurement of the lead with non-treated surface in atmosphere above acetic acid solution in various concentrations, effect of $\mathrm{VCl}$ is represented as loss of the lead foil thickness in time

Table 1 The values of corrosion rate ( $\left.r_{\text {corr }}\right)$ of the lead with non-treated surface during different parts of resistometric measurement expressed in $\mu \mathrm{m}$ per year

\begin{tabular}{|c|c|c|c|c|}
\hline$r_{\text {corr }}\left(\mu \mathrm{m} \cdot\right.$ year $\left.^{-1}\right)$ & air & $\begin{array}{c}0.001 \mathrm{~mol} \cdot \mathrm{l}^{-1} \text { acetic } \\
\text { acid solution }\end{array}$ & $\begin{array}{c}0.01 \text { mol } \mathrm{I}^{-1} \text { acetic acid } \\
\text { solution }\end{array}$ & $\begin{array}{l}0.1 \mathrm{~mol}^{-\mathrm{l}^{-1}} \text { acetic } \\
\text { acid solution }\end{array}$ \\
\hline without inhibitor & -6.1 & -0.2 & 15994 & - \\
\hline BTA & -0.9 & -0.2 & 3.5 & 4575 \\
\hline cyclohexylamine carbonate & -0.9 & -0.9 & 0.1 & 0.8 \\
\hline dicyclohexylamine nitrite & -0.6 & 0.4 & 124 & 1649 \\
\hline urotropine & -2.6 & -0.3 & -0.3 & 1264 \\
\hline sodium benzoate & -5.3 & -0.9 & -1.8 & -0.9 \\
\hline
\end{tabular}

Visual observation of the sensors after resistometric measurement (Figure 2) confirmed resistometric data. Only for cyclohexylamine carbonate the whole sensor surface looks bright and shiny in opposite of the BTA and without inhibitor sensors, where general corrosion occurs. For another VCls the lead corrosion mainly took place in a few small areas.
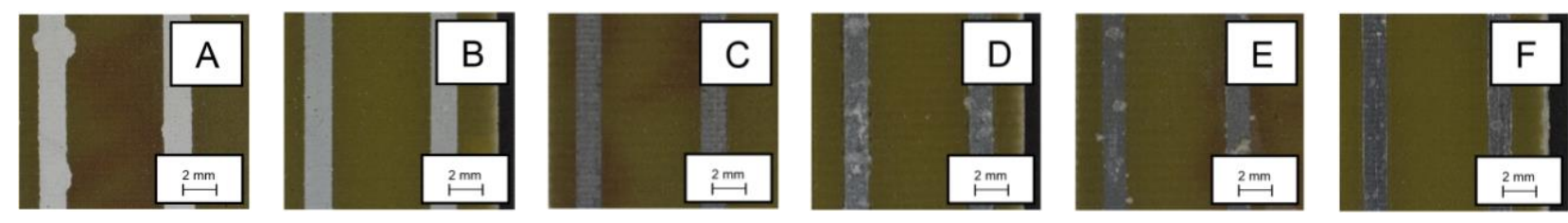

Figure 2 Visual observation of sensors after resistometric measurement, exposition without inhibitor $(\mathbf{A})$, with BTA (B), cyclohexylamine carbonate $(\mathbf{C})$, dicyclohexylamine nitrite $(\mathbf{D})$, urotropine $(\mathbf{E})$, sodium benzoate $(\mathbf{F})$ 


\subsection{Weight gain technique}

General observation on (Figure 3) is an evident increase of weight gain with corroded surface state and with concentration of acetic acid solution $0.1 \mathrm{~mol}^{-\mathrm{l}^{-1}}$. From (Figure 3) and Table 2, it can be observed that lead with non-treated surface and protected by cyclohexylamine carbonate has the highest corrosion resistant in the environment of any concentration of acetic acid. For the lead with corroded surface (Figure 3) and Table $\mathbf{3}$ is in the atmosphere above 0.01 and $0.1 \mathrm{~mol}^{-1}$ acetic acid solution, the best performance was shown by urotropine. In the atmosphere above $0.001 \mathrm{~mol}^{-1}{ }^{-1}$ acetic acid solution all tested VCls failed to protect lead with corroded surface. Only in the atmosphere above $0.01 \mathrm{~mol}^{-1}$ acetic acid solution all tested VCls protected lead with both surface states. Dicyclohexylamine nitrite failed for both lead surface states in all environments. The biggest consumption of $\mathrm{VCls}$ during the weight gain measurements (in the atmosphere above acetic acid solution in concentration $0.001,0.01$ and $\left.0.1 \mathrm{~mol}^{-1}\right)$ was for cyclohexylamine carbonate $(2,3$ and $6 \mathrm{~g})$. The other VCls were consumed only in atmosphere above $0.1 \mathrm{~mol} \cdot \mathrm{H}^{-1}$ acetic acid solution, BTA $2 \mathrm{~g}$, dicyklohexylamine nitrite $2 \mathrm{~g}$, urotropine $1 \mathrm{~g}$ and sodium benzoate $0 \mathrm{~g}$.

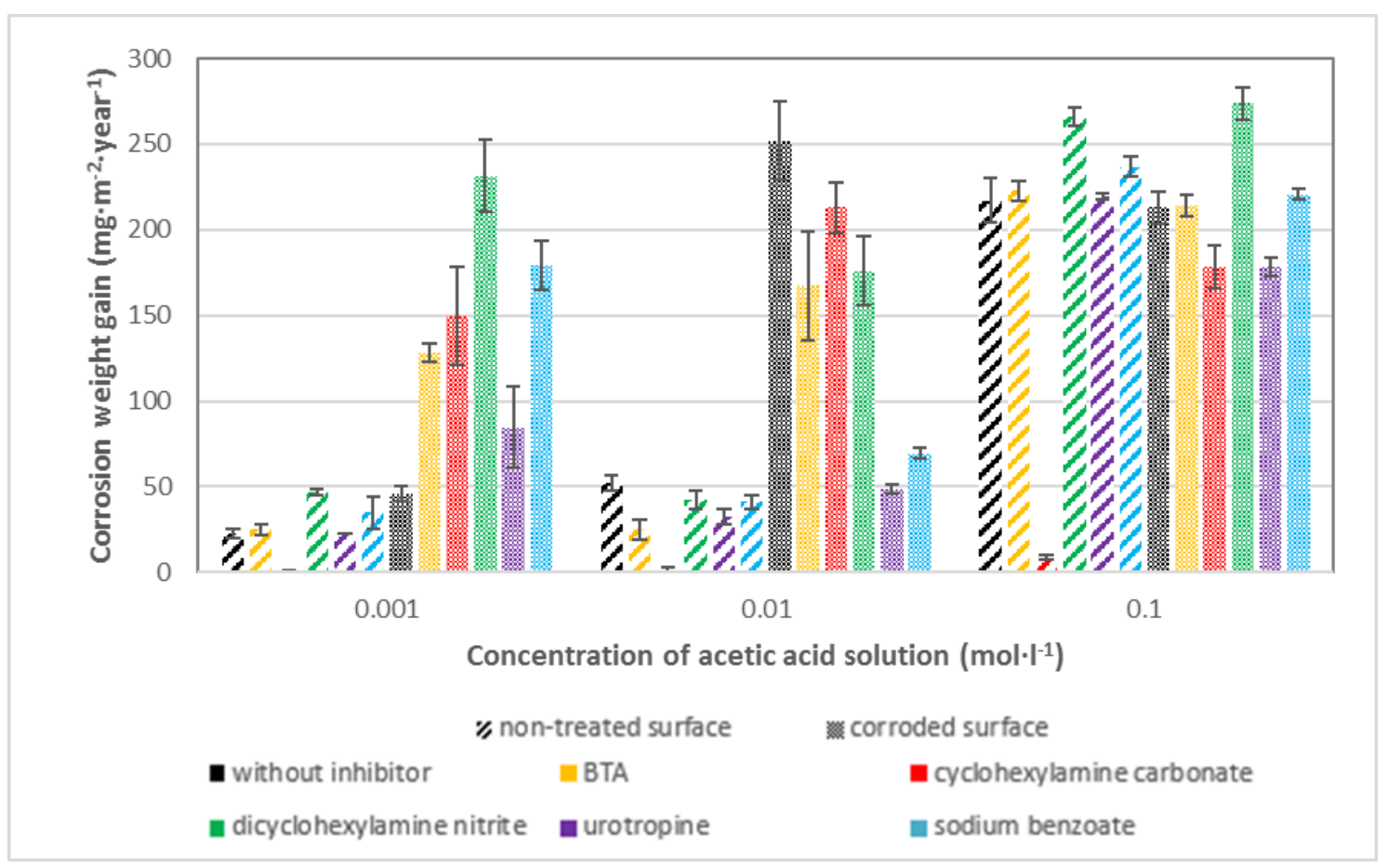

Figure 3 Weight gain measurement of the lead with non-treated and corroded surface in atmosphere above acetic acid solution in various concentrations, effect of $\mathrm{VCl}$ is represented as the average corrosion rate of lead samples

Table 2 The average values of corrosion rate $\left(r_{\mathrm{mi}}\right)$ of the lead with non-treated surface in atmosphere above acetic acid solution in various concentrations and $\mathrm{VCl}$ expressed in $\mathrm{mg}$ per year and meter square

\begin{tabular}{|c|c|c|c|c|c|c|}
\hline \multirow{2}{*}{$\begin{array}{l}\text { Concentration of } \\
\text { acetic acid } \\
\text { solution }\left(\mathrm{mol} \cdot \mathrm{l}^{-1}\right)\end{array}$} & \multicolumn{6}{|c|}{$r_{\mathrm{mi}}\left(\mathrm{mg} \cdot \mathrm{m}^{-2} \cdot\right.$ year $\left.^{-1}\right)$} \\
\hline & $\begin{array}{l}\text { without } \\
\text { inhibitor }\end{array}$ & BTA & $\begin{array}{l}\text { cyclohexylamine } \\
\text { carbonate }\end{array}$ & $\begin{array}{c}\text { dicyclohexylamine } \\
\text { nitrite }\end{array}$ & urotropine & $\begin{array}{l}\text { sodium } \\
\text { benzoate }\end{array}$ \\
\hline 0.001 & $23 \pm 3$ & $25 \pm 3$ & $-3 \pm 5$ & $47 \pm 2$ & $23 \pm 0$ & $35 \pm 9$ \\
\hline 0.01 & $52 \pm 5$ & $25 \pm 6$ & $-2 \pm 5$ & $42 \pm 5$ & $33 \pm 5$ & $41 \pm 4$ \\
\hline 0.1 & $217 \pm 13$ & $223 \pm 6$ & $9 \pm 2$ & $266 \pm 6$ & $219 \pm 2$ & $237 \pm 6$ \\
\hline
\end{tabular}


Table 3 The average values of corrosion rate $\left(r_{\mathrm{mi}}\right)$ of the lead with corroded surface in atmosphere above acetic acid solution in various concentrations and $\mathrm{VCl}$ expressed in $\mathrm{mg}$ per year and meter square

\begin{tabular}{|c|c|c|c|c|c|c|}
\hline \multirow{2}{*}{$\begin{array}{c}\text { Concentration of } \\
\text { acetic acid } \\
\text { solution }\left(\mathbf{m o l} \cdot \mathbf{l}^{-1}\right)\end{array}$} & $\begin{array}{c}\text { without } \\
\text { inhibitor }\end{array}$ & BTA & $\begin{array}{c}\text { ryclohexylamine } \\
\text { carbonate }\end{array}$ & $\begin{array}{c}\text { dicyclohexylamine } \\
\text { nitrite }\end{array}$ & urotropine & $\begin{array}{c}\text { sodium } \\
\text { benzoate }\end{array}$ \\
\cline { 2 - 7 } & $46 \pm 5$ & $128 \pm 6$ & $150 \pm 29$ & $231 \pm 21$ & $85 \pm 24$ & $179 \pm 14$ \\
\hline 0.001 & $252 \pm 23$ & $167 \pm 32$ & $213 \pm 15$ & $176 \pm 20$ & $49 \pm 3$ & $70 \pm 3$ \\
\hline 0.01 & $213 \pm 9$ & $214 \pm 6$ & $178 \pm 13$ & $274 \pm 9$ & $178 \pm 6$ & $221 \pm 3$ \\
\hline 0.1 & & & & & \\
\hline
\end{tabular}

In the atmosphere above 0.001 and $0.01 \mathrm{~mol} \cdot \mathrm{I}^{-1}$ acetic acid solution and cyclohexylamine carbonate whole lead samples with non-treated surface remained clear, bright and shiny, in the atmosphere above $0.1 \mathrm{~mol}^{-1} \mathrm{f}^{-1}$ acetic acid solution and cyclohexylamine carbonate lead surface tarnished. For lead with corroded surface in environments of any concentration of acetic acid is cyclohexylamine carbonate the worst $\mathrm{VCl}$ (the whole lead samples surface turned white and oily and covered with white blisters). The urotropine provided acceptable corrosion protection (mainly the lead surface tarnished) for both lead surface states in the atmosphere above 0.001 and $0.01 \mathrm{~mol} \cdot \mathrm{l}^{-1}$ acetic acid solution, but in the atmosphere above $0.1 \mathrm{~mol} \cdot \mathrm{f}^{-1}$ acetic acid solution and urotropine lead corroded.

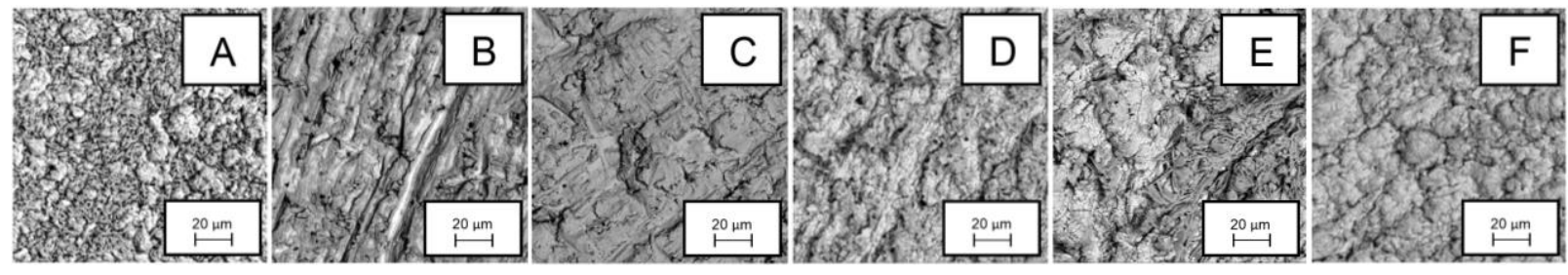

Figure 4 SEM picture of lead samples with non-treated surface exposed in atmosphere above $0.001 \mathrm{~mol} \cdot \mathrm{I}^{-1}$ acetic acid solution and with or without VCls, without inhibitor (A), BTA (B), cyclohexylamine carbonate (C), dicyclohexylamine nitrite $(\mathbf{D})$, urotropine $(\mathbf{E})$, sodium benzoate $(\mathbf{F})$

Table 4 Summary of XRD analyses for lead samples with non-treated surface exposed in atmosphere above $0.001 \mathrm{~mol} \cdot \mathrm{I}^{-1}$ acetic acid solution and with or without VCls, the compound occurs on the surface very well (5), the compound occurs on the surface (3), the compound occurs on the surface weakly (2) and the compound occurs on the surface very weakly (1)

\begin{tabular}{|c|c|c|c|c|c|}
\hline & $\begin{array}{c}\text { Lead } \\
\mathrm{Pb}\end{array}$ & $\begin{array}{c}\text { Hydrocerussite } \\
\mathrm{Pb}_{3}\left(\mathrm{CO}_{3}\right)_{2}(\mathrm{OH})_{2}\end{array}$ & $\begin{array}{c}\text { Plumbonacrite } \\
\mathrm{Pb}_{5}\left(\mathrm{CO}_{3}\right)_{3} \mathrm{O}(\mathrm{OH})_{2}\end{array}$ & $\begin{array}{c}\text { Trilead dioxo diacetate } \\
\text { hemihydrate } \\
\mathrm{Pb}_{3} \mathrm{O}_{2}\left(\mathrm{CH}_{3} \mathrm{COO}\right)_{2}\left(\mathrm{H}_{2} \mathrm{O}_{0.5}\right.\end{array}$ & $\begin{array}{c}\text { Lead } \\
\text { acetate } \\
\mathrm{C}_{2} \mathrm{H}_{6} \mathrm{O}_{4} \mathrm{~Pb}\end{array}$ \\
\hline without inhibitor & 5 & 2 & 3 & 3 & 1 \\
\hline BTA & 5 & 2 & 3 & 1 & - \\
\hline $\begin{array}{c}\text { cyclohexylamine } \\
\text { carbonate }\end{array}$ & 5 & 2 & 2 & 2 & - \\
\hline $\begin{array}{c}\text { dicyclohexylamine } \\
\text { nitrite }\end{array}$ & 5 & 2 & 5 & 3 & 1 \\
\hline urotropine & 5 & 2 & 2 & 2 & 1 \\
\hline sodium benzoate & 5 & 2 & 3 & & 1 \\
\hline
\end{tabular}


SEM observation (Figure 4) and XRD analyses Table 4 of lead samples with non-treated surface exposed in atmosphere above $0.001 \mathrm{~mol} \cdot \mathrm{I}^{-1}$ acetic acid solution and with or without VCls confirm the greatest inhibition efficiency of cyclohexylamine carbonate. Lead acetate did not occur on the lead surface in the presence of cyclohexylamine carbonate and BTA (nevertheless, in the presence of BTA lead corrodes).

\section{CONCLUSION}

In an atmosphere polluted by acetic acid, cyclohexylamine carbonate provided the most effective protection (high corrosion protection with the minor surface appearance changes) for lead with non-treated surface and acceptable corrosion protection but high surface appearance change for lead with corroded surface in atmosphere with high concentration of acetic acid. Another important aspect and applicability limitation in the same time is the nasty stench of cyclohexylamine carbonate. Other and possibly recommended VCl which provides acceptable protection of lead (mainly for lead with corroded surface) with some surface appearance changes is urotropine.

\section{ACKNOWLEDGEMENTS}

\section{The authors gratefully acknowledge the financial support by the Czech Ministry of Culture under NAKI II programme (No. DG16P02R040).}

\section{REFERENCES}

[1] SASTRI, V. S. Vapor phase corrosion inhibitors. In: SASTRI, V.S. Corrosion Inhibitors Principles and Aplications, 1 st ed. Chichester: John Wiley and Sons Ltd, 1998, pp. 787-822.

[2] GANGOPADHYAY, S., MAHANWAR, P.A. Recent developments in the volatile corrosion inhibitor (VCl) coatings for metal: a review. Journal of Coatings Technology and Research. 2018. vol. 15, pp. 789-807.

[3] RAJA, P. B., ISMAIL, M., GHOREISHIAMIRI, S., MIRZA, J., ISMAIL, M. C., KAKOOEI, S., RAHIM, A. A. Corrosion Inhibitors: A Short View. Chemical Engineering Communications. 2016, vol. 203, no. 9, pp. 1145-1156.

[4] KREISLOVÁ, K. Inhibitory koroze. Koroze a ochrana materiálu. 1996, vol. 40, no. 2, pp. 25-29.

[5] RAMMELT, U., KOEHLER, S., REINHARD, G. Use of vapour phase corrosion inhibitors in packages for protecting mild steel against corrosion. Corrosion Science. 2009, vol. 51, pp. 921-925.

[6] NOVÁK, P. Konzervování a restaurování olova a jeho slitin. In: Kolektiv autorů. Konzervování a restaurování kovů, 1 st ed. Brno: Technické muzeum v Brně, 2011, pp. 526-544.

[7] ENGLISH HERITAGE. Guidelines for the Storage and Display of Archaeological Metalwork [Online]. [viewed 2018-04-22]. Available from: http://www.englishheritage.org.uk/content/learn/conservation/2543455/2543024/guidelines-for-the-storage-and-display-ofarchaeological-metalwork.pdf.

[8] GIBSON, L. T., WATT, C. M. Acetic and formic acids emitted from wood samples and their effect on selected materials in museum environments. Corrosion Science. 2010, vol. 52, pp. 172-178.

[9] ĎUROVIČ, M., et al. Restaurování a konzervování archiválii a knih. Praha: Paseka, 2002.

[10] HATCHFIELD, B. P. Pollutants in the Museum Environment. London: Archetype Publications, 2002.

[11] NIKLASSON, A., JOHANSSON, L., SVENSSON, J. Atmospheric corrosion of historical organ pipes influence of acetic and formic acid vapour and water leaching on lead. In METAL 2014: 23rd International Conference on Metallurgy and Materials. Ostrava: TANGER, 2014, pp. 273-279.

[12] CANO, E., LAFUENTE, D. Corrosion inhibitors for the preservation of metallic heritage artefacts. In: DILLMANN, P., WATKINSON, D., ANGELINI, E., ADRIAENS, A., eds. Corrosion and conservation of cultural heritage metallic artefacts, 1 st ed. Oxford: Woodhead Publishing Limited, 2013. pp 570-594.

[13] STRACHOTOVÁ, K. C., KUCHŤÁKOVÁ, K., KOUŘIL, M., MSALLAMOVÁ, Š. Protection of lead in acetic acid containing air by means of corrosion inhibitors. In METAL 2018: 27th International Conference on Metallurgy and Materials. Ostrava: TANGER, 2018, pp. 1045-1050. 